\title{
A model of the labor productivity dependence on workforce density
}

\author{
Boris Pergamenshchik and Vadim Undozjorov* \\ Moscow State University of Civil Engineering, Yaroslavskoe shosse, 26, Moscow, 129337, Russia
}

\begin{abstract}
The paper reviews the dependence of labor productivity on the number of workers within a unit of working area (i.e. workforce density) in the construction sector. The relevance of the problem is demonstrated. Some limitations of the linear model for the dependence, assumed in the construction sector, are discussed. These limitations are linked up with the neglect of labor productivity reduction due to the increased density. The proposed by some researchers concepts which account for the above factor are listed. Their drawbacks are indicated, and the necessity of further research is shown. A "hyperbolic model" is proposed, in which one worker productivity is constant for a certain workforce density rate and then it drops down with the increasing speed. Work productivity reduction in such model is described by the "hyperbolic growth" function. The primary approbation of the model was done for some construction operations at the nuclear power plant reactor building. The density rate was optimized (as per deadline reduction criterion) for this case according to the "hyperbolic model".
\end{abstract}

\section{Introduction}

It is accepted in calendar and network planning in the construction sector that the total team output linearly depends on the workforce density (the number of workers within a unit of working area). However, in the case of limited work front one worker productivity rate is constant only until the working space is not congested, and the more workers are involved in the operations the greater is their common productivity. It is so until the workforce density achieves a certain level when productivity is affected by mutual interferences. The total team output may nevertheless increase until a certain optimal level is achieved. Then the overall productivity starts dropping down because of the work space congestion. Modeling the dependence of labor productivity on the workforce density may allow finding the mentioned optimum as well as improving the accuracy of calendar planning.

There were attempts to solve the problem of the workforce productivity reduction modeling caused by the increased density by such autors as M. Ringelmann [1, 2], E.Mayo, M. S. Viteles [3], D. Hewitt, J. Parfit [4], B. V. Lukanin [5], I. V. Kim [6], G. L. Isaeva [7], F. F. Dzhalilov [8], T. L. Simankina [9], I. L. Abramov [10], M.Kaya [11], J. Lee [12], A. A. Lapidus [13], etc. Most of the proposed models for one worker productivity $(P)$ dependence on the workforce density $(\rho)$ are presented in $((1),(2),(3))$ as follows:

\footnotetext{
* Corresponding author: und-vadim@yandex.ru
} 


$$
P=P_{0}=\text { const }, \quad \text { for } \rho \leq \rho_{l}
$$

with $P_{0}\left(\frac{\text { product units }}{\text { man-hour }}\right)$ as nominal work efficiency, commonly defined in construction codes $(« \mathrm{ENiR} », « \mathrm{FER} »$, etc. $) ; \rho_{l}\left(\frac{\text { men }}{\text { space unit }}\right)$ as "linearity limit", i.e. density rate that starts one worker labor productivity reduction.

$$
P=P(\rho), \quad \text { for } \rho_{l} \leq \rho \leq \rho_{\max }
$$

with $P(\rho)$ ( $\left.\frac{\text { product units }}{\text { man-hour }}\right)$ as a monotone decreasing function; $\rho_{\max }$ as maximum workforce density that practically makes the work impossible. $\rho_{l}$ and $\rho_{\max }$ are determined either by expert evaluation or by production experiment and depend on the work type.

$$
P\left(\rho_{\max }\right)=0
$$

The total team output $Y$ ( $\left.\frac{\text { product units }}{\text { hour }}\right)$ is defined by the following formula:

$$
Y(\rho)=P \cdot S \cdot \rho
$$

with $S$ (space units) as the size of the working area.

\section{Materials and methods}

The difference of the proposed approaches consists in selection of function $P(\rho)$ that reflects labor productivity reduction versus the workforce density (Cf. Eq.(2)). Meanwhile all proposed functions have either some considerable theoretical drawbacks and/or a narrow application area. [14] In the paper [14] the proposal that pretends to do away with the indicated drawbacks is stated and substantiated. It states that a productivity reduction can be described with a "hyperbolic growth" function (the general form is $f(x)=\frac{C_{2}}{C_{1}-x}$, with $C_{1}, C_{2}$ as parameters, $x$ as a variable $\left.[15,16]\right)$. The results of use this hypothesis for some reinforcement operations were proved by the interviews of the construction engineers at the Novovoronezh Nuclear Power Plant II, made in May 2018. The productivity reduction, in term of such "hyperbolic" model, can be described by the following formula:

$$
P(\rho)=P_{a} \cdot(1-N(\rho))=P_{a} \cdot\left(1-\frac{C_{2}}{C_{1}-S \cdot \rho}\right)
$$


with $P_{a}$ as horizontal asymptote of function $P(\rho)$ (Cf. Fig. 1);

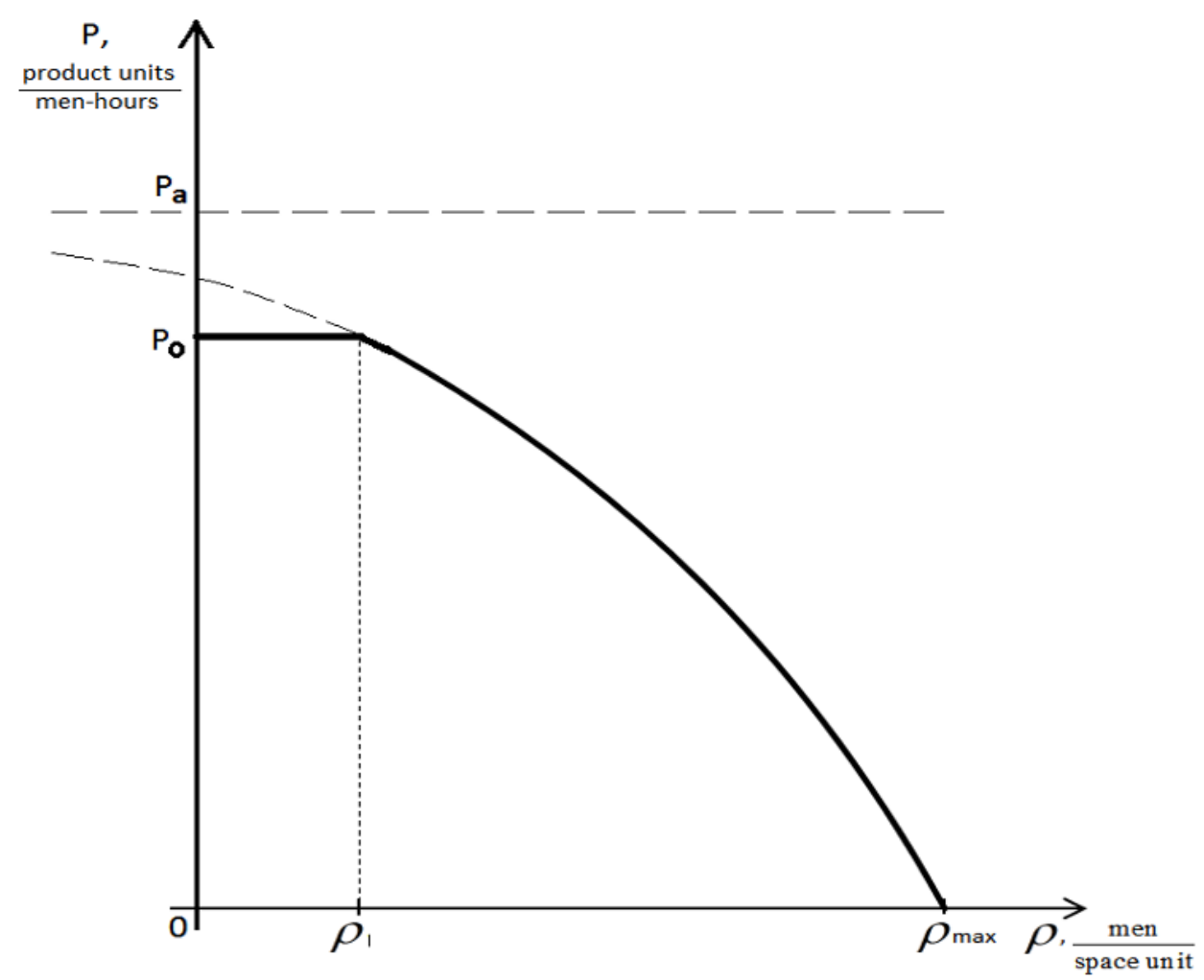

Fig. 1. One worker productivity versus workforce density as per "hyperbolic model" (continuous line) $N(\rho)=\frac{C_{2}}{C_{1}-S \cdot \rho}$ as function, reflecting negative impact of mutual interferences on labor productivity. Parameters $C_{1}$ and $C_{2}$ (men) depend on type of operations with $\frac{C_{1}}{S}$, being the vertical asymptote of function $N(\rho)$ graph (Cf. Fig. 2). $C_{1}$ is limited by condition: $C_{1}>\rho_{\max } \cdot S$. 


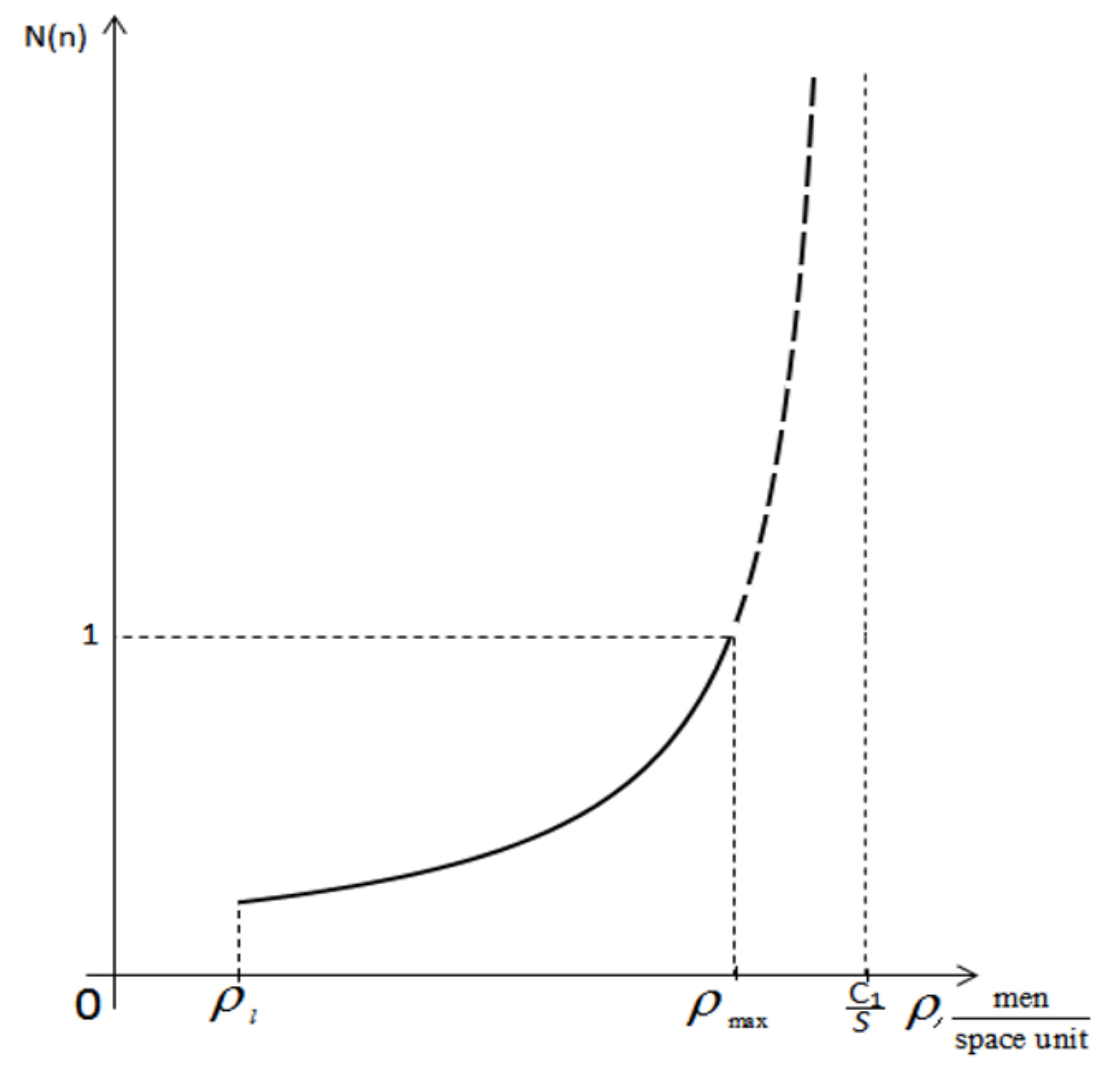

Fig. 2. Function that reflects the negative impact of mutual interferences on labor productivity, depending on the workforce density for the "hyperbolic model" (continuous line) application.

It follows from the boundary conditions:

$$
\begin{gathered}
P\left(\rho_{l}\right)=P_{0}=P_{a} \cdot\left(1-\frac{C_{2}}{C_{1}-S \cdot \rho_{l}}\right) \\
P\left(\rho_{\max }\right)=P_{a} \cdot\left(1-\frac{C_{2}}{C_{1}-S \cdot \rho_{\max }}\right)=0
\end{gathered}
$$

that the formula of labor productivity dependence on the workforce density with $\rho_{l} \leq \rho \leq \rho_{\max }(5)$ can be presented as follows:

$$
P(\rho)=P_{0} \cdot \frac{\left(C_{1}-S \cdot \rho_{l}\right) \cdot\left(\rho_{\max }-\rho\right)}{\left(\rho_{\max }-\rho_{l}\right) \cdot\left(C_{1}-S \cdot \rho\right)}
$$


Parameter $C_{1}$ (men) is determined from the known one worker productivity $P\left(\rho_{0}\right)$ with workforce density $\rho_{0} \in\left(\rho_{l}, \rho_{\max }\right)$ by inserting these values into the above mentioned equation:

$$
C_{1}=\frac{S \cdot\left[\rho_{i} \cdot P_{0} \cdot\left(\rho_{\text {max }}-\rho_{0}\right)-\rho_{0} \cdot P\left(\rho_{0}\right) \cdot\left(\rho_{\text {max }}-\rho_{l}\right)\right]}{P_{0} \cdot\left(\rho_{\text {max }}-\rho_{0}\right)-P\left(\rho_{0}\right) \cdot\left(\rho_{\text {max }}-\rho_{l}\right)}
$$

$P\left(\rho_{0}\right)$ is determined by expert evaluation or by production experiment.

The total team output dependence versus workforce density is given on Fig. 3

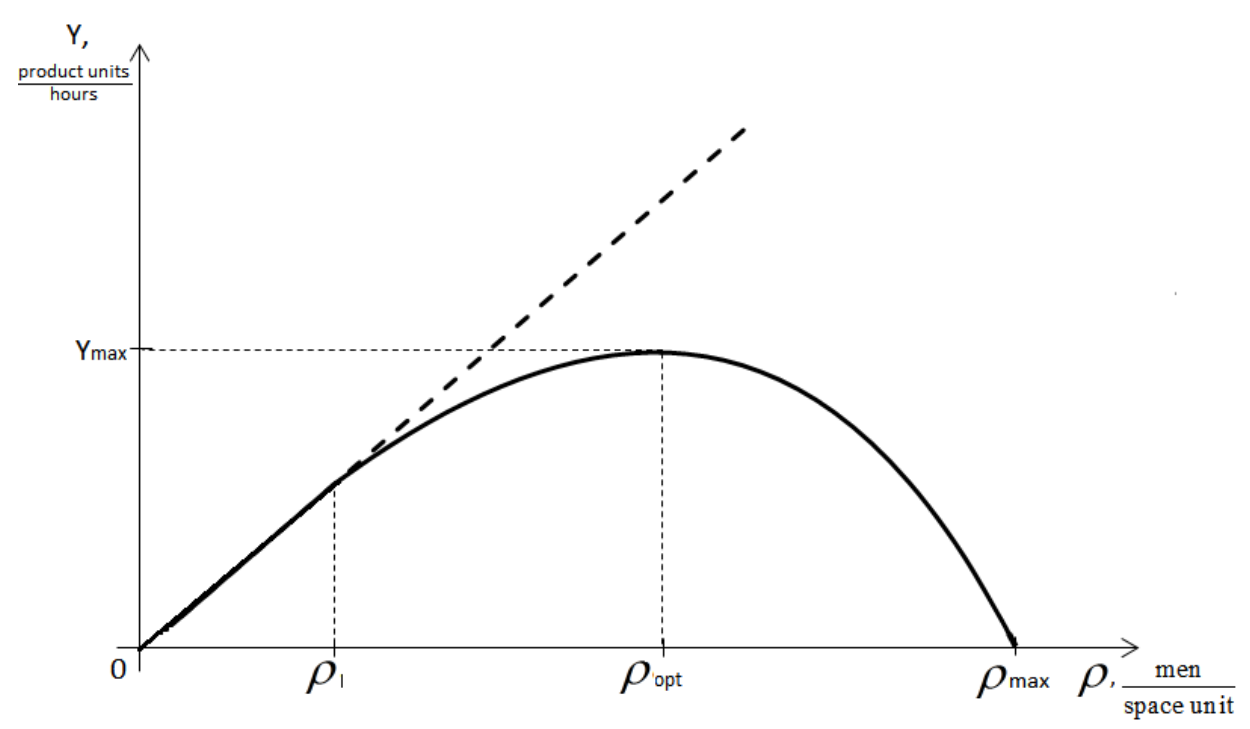

Fig. 3. Total team output versus workforce density: continuous line corresponds to the "hyperbolic model", the dotted line corresponds to the linear model.

$$
Y_{\max } \text { is maximum total team output }
$$

The optimal saturation $\boldsymbol{n}_{\text {opt }}$ as per the work time reduction criterion is determined by the total team output derivative made equal to zero (Cf. (4), (6)):

$$
\rho_{\text {opt }}=\frac{C_{1}-\sqrt{C_{1} \cdot\left(C_{1}-S \cdot \rho_{\max }\right)}}{S}
$$




\section{Results}

The "hyperbolic model" has been primarily tested for the reinforcement of the base plate of the reactor building of the nuclear power plant (AES-2006) (Cf. Fig. 4).
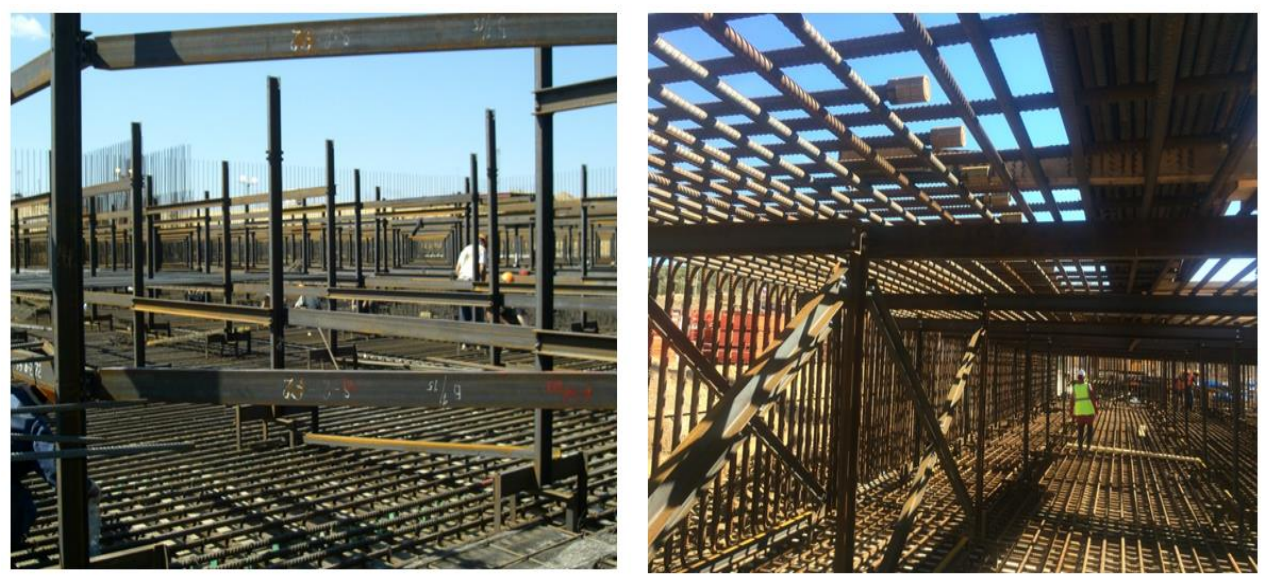

Fig. 4. The reinforcement of the base plate of the reactor building of the nuclear power plant (AES2006)

Parameters $P_{0}, \rho_{l}, \rho_{\max }, C_{1}$ were determined according to the results of the survey of the experts (Novovoronezh NPP II construction specialists). Work front area $S$ was found out from the project documentation. Values are presented in Table 1.

Table 1. Initial conditions for the case

\begin{tabular}{|l|c|c|c|}
\hline \multicolumn{1}{|c|}{ Value } & Notation & Value & Unit \\
\hline Work area & $S$ & 2100 & $\mathrm{~m}^{2}$ \\
\hline Nominal worker productivity & $P_{0}$ & 0,017 & $\frac{\text { tons }}{\text { man-hour }}$ \\
\hline «Linearity limit» & $\rho_{l}$ & 2,38 & $\frac{\text { men }}{100 \mathrm{~m}^{2}}$ \\
\hline Maximum workforce density rate & $\rho_{\text {max }}$ & 10,95 & $\frac{\mathrm{men}^{2}}{100 \mathrm{~m}^{2}}$ \\
\hline Parameter $C_{1}$ & $C_{1}$ & 470 & men \\
\hline
\end{tabular}

As a result of calculation by the formulas of the "hyperbolic model", the values of labor productivity and the total team output depending on the workforce density were obtained. It is presented in Table 2 . 
Table 2. One worker productivity and total team output for different workforce density rates under the assumption of "hyperbolic model" for the case in question

\begin{tabular}{|l|c|c|c|c|c|c|c|c|}
\hline $\begin{array}{l}\text { Workforce } \\
\text { density, } \\
\frac{\mathrm{men}}{100 \mathrm{~m}^{2}}\end{array}$ & $\mathbf{0 , 0 9 5}$ & $\mathbf{0 , 9 5}$ & $\begin{array}{l}\mathbf{2 , 3 8} \\
\left(\rho_{l}\right)\end{array}$ & $\mathbf{3 , 8}$ & $\begin{array}{l}\mathbf{6 , 3 8} \\
\left(\boldsymbol{\rho}_{o p t}\right.\end{array}$ & $\mathbf{7 , 6 2}$ & $\mathbf{9 , 5 2}$ & $\mathbf{1 0 , 9 5}$ \\
\hline $\begin{array}{c}\text { Number of } \\
\text { workers, men }\end{array}$ & $\mathbf{2}$ & $\mathbf{2 0}$ & $\mathbf{5 0}$ & $\mathbf{8 0}$ & $\mathbf{1 3 4}$ & $\mathbf{1 6 0}$ & $\mathbf{2 0 0}$ & $\begin{array}{c}\mathbf{2 3 0} \\
\left(\boldsymbol{n}_{\max }\right)\end{array}$ \\
\hline $\begin{array}{l}\text { Specific area } \\
\text { per person, } \\
\text { m/man }\end{array}$ & $\mathbf{1 0 5 0}$ & $\mathbf{1 0 5}$ & $\mathbf{4 2}$ & $\mathbf{2 6 , 2}$ & $\mathbf{1 5 , 7}$ & $\mathbf{1 3 , 1}$ & $\mathbf{1 0 , 5}$ & $\mathbf{9 , 1}$ \\
\hline $\begin{array}{l}\text { Worker } \\
\text { productivity, } \\
\text { ton/man-hour }\end{array}$ & 0,017 & 0,017 & 0,017 & 0,015 & $\mathbf{0 , 0 1 1 4}$ & 0,009 & 0,004 & 0 \\
\hline $\begin{array}{l}\text { Team total } \\
\text { output, } \\
\text { ton/hour }\end{array}$ & 0,034 & 0,34 & 0,85 & 1,23 & $\mathbf{1 , 5 2 7}$ & 1,44 & 0,88 & 0 \\
\hline
\end{tabular}

\section{Discussion}

The results, according to experts, are close to true. The performed analysis shows that if spread footing reinforcement operations are to be accelerated to reduce the deadlines or, as is often the case, to meet the planned deadlines, the workforce can be increased from 50 to maximum 130-140 men. This result corresponds to the expert evaluation of optimal value roughly 140 men.

Thus, the first results of testing the model show that it allows us to estimate the dependence of labor productivity on workforce density and the optimal number of workers (according to the work deadline reduction criterion) with pretty high accuracy. At the same time, the model is quite simple, for its use only 3 subjective parameters are necessary. Based on the previously proposed models, it is characterized by better validity and breadth of application area.

\section{Conclusions}

The research enables the following conclusions:

1. The proposed "hyperbolic model" of the workforce productivity dependence on workforce density allows to account the labor productivity reduction due to mutual interference between workers.

2. An algorithm for the finding the optimum of the number of workers (according to the work deadline reduction criterion) which corresponds to the maximum total team output is offered.

3. The "hyperbolic model" has been initially successfully tested at the reinforcement operations for the spread footing of a Nuclear Power Plant reactor building. The number of workers was optimized according to deadline reduction criterion.

4. The model is able to be used as a tool of solving a number of problems of calendar planning and workforce rate optimization. 


\section{References}

1. A. Simms, T. Nichols Social Loafing: A Review of the Literature. Journal of Management Policy and Practice, vol. 15, issue 1, pp. 58-67 (2014)

2. P. Vermeulen, J. Benders A reverse side of the team medal. Team Performance Management: An International Journal, vol. 9, issue: 5/6, pp. 107-114 (2003)

3. M. S. Viteles Motivation and Moral in Industry. W. W. Norton \& Co. New York, p. 134 (1953)

4. D. Hewitt, J. Parfit On Working Morale and Size of Group. Occupational Psychology (1953)

5. B. V. Lukanin Determination of the optimal number of workers in construction and installation work // Tekhnicheskaya informaciya. Gosstroj Kazahskoj SSR, respublikanskij centr nauchno-tekhnicheskoj informacii po stroitel'stvu, stroitel'nomu proektirovaniyu i inzhenernym izyskaniyam. [Technical information. Gosstroy of the Kazakh SSR, the republican center of scientific and technical information on construction, construction design and engineering surveys], no 10 (1970) (in Russian).

6. I. V. Kim Investigation of the influence of the duration of construction on the economics of construction organizations. PhD Thesis. Moscow (1974) (in Russian)

7. G. L. Isaeva Investigation of methods of rational saturation of the front with labor resources and mechanization means. PhD Thesis. Volgograd (1975). (in Russian).

8. F. F. Dzhalilov Development of methods for the formation of organizational and technological solutions for the reconstruction of existing enterprises. $\mathrm{PhD}$ Thesis. Moscow (1996) (in Russian)

9. T. L. Simankina Improving the scheduling of resource-saving flows, taking into account the additivity of the intensity of labor of performers. $\mathrm{PhD}$ Thesis. $\mathrm{SPb}$ (2007) (in Russian)

10. I. L. Abramov Modeling of technological processes in low-rise housing construction. PhD Thesis. Moscow (2007) (in Russian)

11. M. Kaya, A. E. Keles, E. L. Oral Construction Crew Productivity Prediction by Using Data Mining Methods. Procedia - Social and Behavioral Sciences, vol. 141, pp. 1249 $1253(2014)$

12.J. Lee, Y.-J. Park, Ch.-H. Choi, Ch.-H. Han BIM-assisted labor productivity measurement method for structural formwork. Automation in Construction, vol. 84, pp. 121-132 (2017)

13. A. A. Lapidus, K. S. Tolstova Kriterij ocenki dopustimosti sovmeshcheniya stroitel'nyh processov pri proizvodstve otdelochnyh rabot $v$ zhilyh zdaniyah [The criterion for assessing the admissibility of combining construction processes in the production of finishing works in residential buildings] // Promyshlennoe i grazhdanskoe stroitel'stvo, no. 5, pp. 68-71 (2016) (in Russian)

14. B. K. Pergamenshchik, V. A. Undozjorov Proizvoditel'nost' truda v stroitel'stve $v$ funkcii nasyshchennosti fronta rabot trudovymi resursami [Labor productivity in the construction industry in the function of the saturation of the work front by the labor resource] // Ehkonomika stroitel'stva, no. 5, pp. 25-34 (2018) (in Russian).

15. A. V. Markov, A. V. Korotaev A Hyperbolic growth in wildlife and society. Moscow, 200 p. (2009) (in Russian)

16. S. P. Kapitsa Paradoxes of growth. The laws of human development. Moscow, 204 p. (2012) (in Russian) 